\title{
The endodontic system of equine cheek teeth: a re- examination of pulp horns and root canals in view of age-related physiological differences
}

\author{
Hagen Gasse, Elmar Westenberger and Carsten Staszyk \\ Institute of Anatomy, School of Veterinary Medicine Hannover
}

\begin{abstract}
Summary
The pulp horns and the root canals of the endodontic system of selected cheek teeth (left upper and left lower P3 = 207/307, M1 = 209/309) from 31 horses of large breeds (124 teeth) were examined in the dissection microscope (cross sections). From the right jaws, corresponding teeth were taken as histological controls to check for a vital pulp. The specimens were assigned to three age groups $(<15$ years; 15-23 years; $>23$ years; the oldest horse had an age of 27 years). Pulp horns had disappeared in many horses by an age of 23 , but were present in a cheek tooth of the upper jaw even in a 25 -year-old horse. Pulp horns disappeared earlier in M1 than in P3. The extension of the pulp horns towards the occlusal surface was markedly unsymmetrical in teeth with an extreme inclination of the occlusal surface. Root canals were regularly present in all (even in the very old) horses. The roots often contained more than one root canal. The number of root canals of the individual root varied especially in the mandibular cheek teeth. The apical foramen was closed in horses older than 23 years, but the pulp remained still vascularized, i.e. "vital" also in the older horses.
\end{abstract}

Keywords: endodontic system, pulp horns, root canals, cheek teeth, age differences, horse

Das endodontische System des Pferdebackenzahns: eine erneute Untersuchung von Pulpaästen und Wurzelkanälen in Hinblick auf altersbedingte physiologische Unterschiede

An ausgewählten Backenzähnen (linke obere und untere P3 = 207/307 und M1 = 209/309) von 31 Pferden (124 Zähne) wurden die Pulpaäste und Wurzelkanäle des endodontischen Systems an Querschnitten bei Lupenvergrößerung untersucht. Die korrespondierenden Zähne der rechten Kiefer wurden histologisch auf das Vorhandensein einer vaskularisierten, d.h. "vitalen" Pulpa kontrolliert. Die Proben wurden drei Altersgruppen zugeordnet (<15 Jahre; 15-23 Jahre; $>23$ Jahre; das älteste Pferd war 27 Jahre alt). Die Pulpaäste waren meistens ab einem Alter von 23 Jahren verschwunden; im Einzelfall bestanden sie aber auch länger, z.B. bei einem 25 Jahre alten Pferd in den Oberkieferbackenzähnen. Im M1 waren sie eher geschlossen als im P3. Ihre okklusale Ausdehnung war unsymmetrisch bei Zähnen mit starker Neigung der Reibefläche. Wurzelkanäle waren stets - auch in den Zähnen der ältesten untersuchten Pferde -vorhanden. Oft enthielt eine Zahnwurzel auch mehr als nur einen Wurzelkanal. Besonders bei den mandibulären Zähnen traten diesbezüglich mehrere Variationsmöglichkeiten auf. Das Wurzelloch war bei Pferden >23 Jahre stets verschlossen. Dennoch enthielt das endodontische System eine vaskularisierte, "vitale" Pulpa auch bei sehr alten Pferden.

Schlüsselwörter: endodontisches System, Pulpaäste, Wurzelkanäle, Backenzahn, Altersunterschiede, Pferd

\section{Introduction}

The dental cavity of the cheek teeth in horses has been the subject of many anatomical and clinical studies. However, in these studies age-related data concerning the extension and the size of the dental cavity show quite a large range of variation (Westenberger 2002). The same is true of data concerning the physiological closure of the root's apical foramen. If one considers that 7 of 8 cases of dental disorders are primarily caused by cheek teeth (Dixon et al. 2000) it seems appropriate to re-examine the dental cavity carefully. Such data may be relevant in terms of two clinical issues: (1) treatment of disorders of dental wear; (2) endodontic treatment of periapical and/or apical infections. Special attention shall, therefore, be paid to two of the different compartments of the endodontic system: (1) the pulp horns; (2) the root canals and their apical foramen.

\section{Material and Methods}

The third premolar cheek tooth (P3 = 207/307) and the first molar cheek tooth (M1 = 209/309) of the left upper jaw and of the left lower jaw were taken from 31 horses of large breeds (no ponies). This yielded a total number of 124 cheek teeth. The teeth were isolated from the jaw together with the adjacent bone. After pre-treatment with $45 \% \mathrm{KOH}$ (immersion), bony tissue was most carefully removed in order to allow a preliminary macroscopical inspection of the dental roots. Afterwards, the teeth were fixed by immersion in 10\% formalin and embedded in epoxy resin (Biodur ${ }^{\circledR}$ E20). The teeth, embedded in the resin blocks, were then cross-cut with a diamond saw. Slices were 5-10 mm thick. They were viewed under a dissection microscope (magnification 7.3 $43.8 \mathrm{x}$ ). For details of the procedure see Westenberger (2002). 

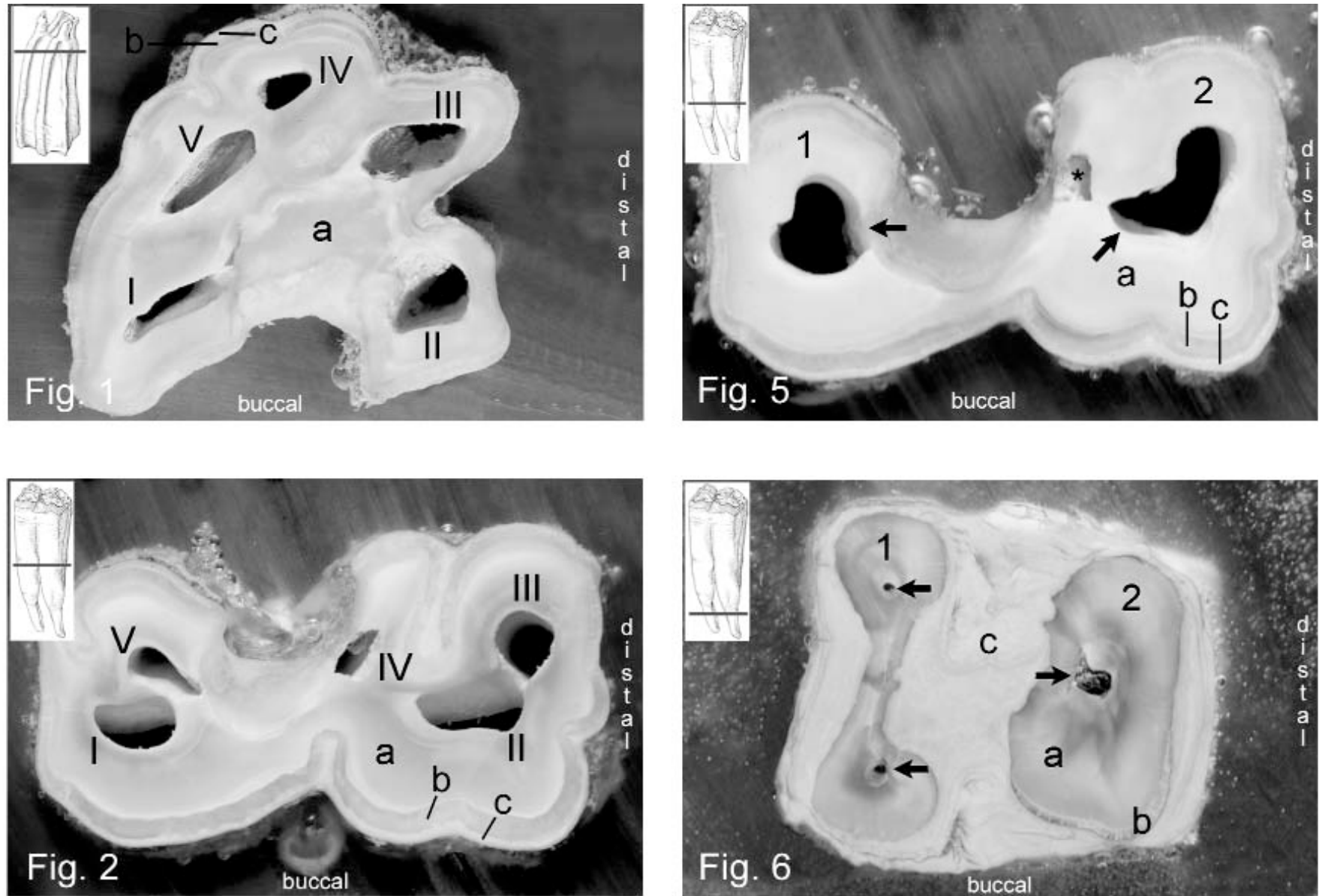

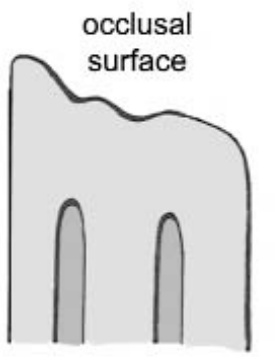

pulp horns

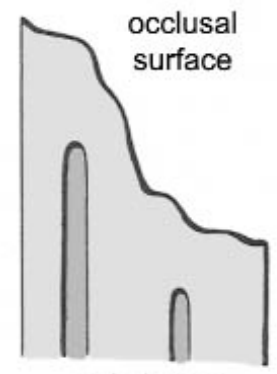

pulp horns

Fig. 3
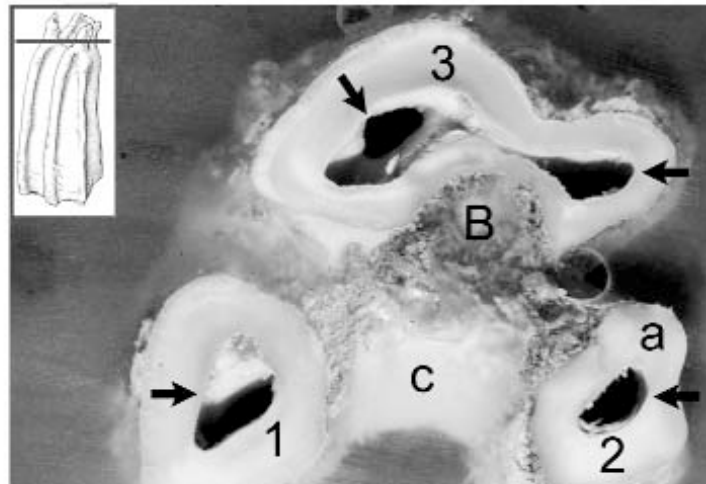

Fig.
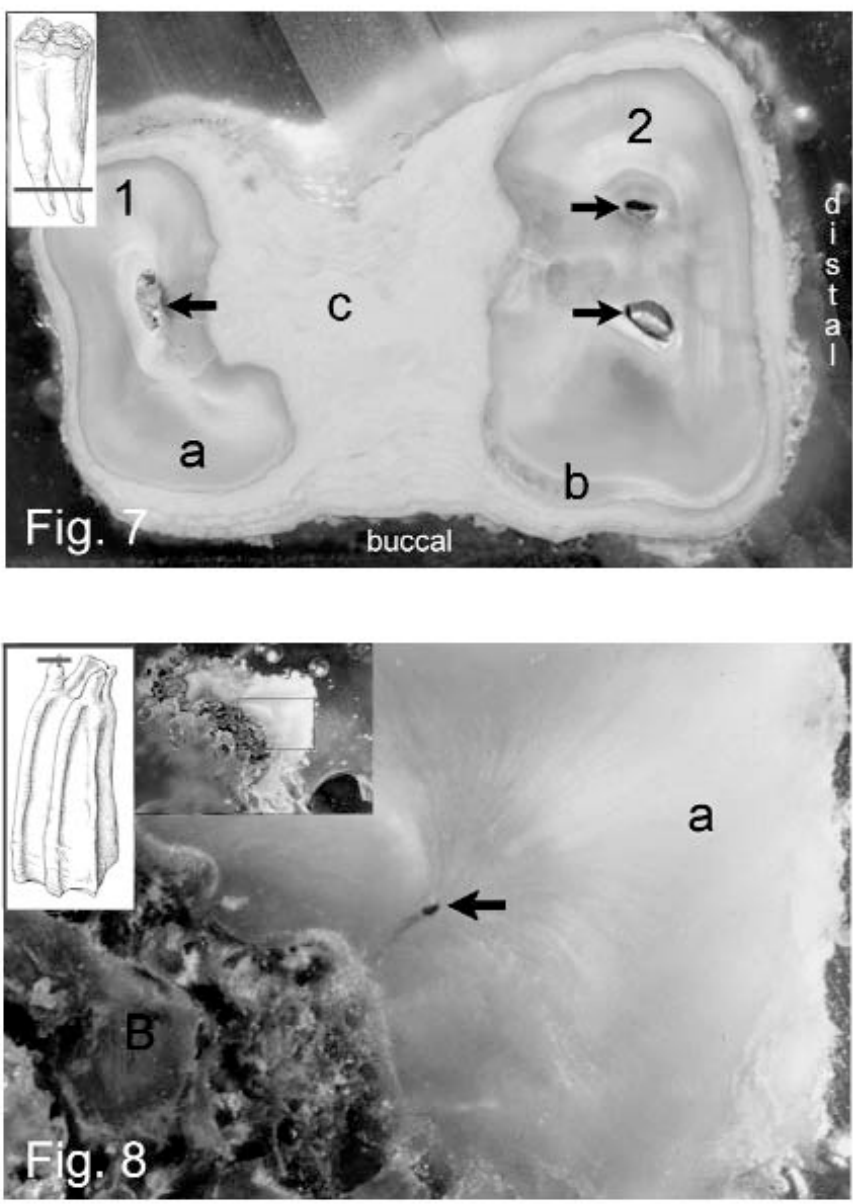

Pferdeheilkunde 20 
Fig 1 Pulp horns in a cross section of an equine third premolar (upper jaw; 207); magnification: $2.7 x$

I - V Numeration of pulp horns according to Obiger (1939) a dentin, $b$ enamel, $c$ cementum

Fig 2 Pulp horns in a cross section of an equine third premolar (lower jaw; 307); magnification: $2.7 x$

I - V Numeration of pulp horns according to Obiger (1939) a dentin, b enamel, c cementum

Fig 3 Schematic drawings of two equine mandibular cheek teeth with different inclinations of occlusal surfaces. Note the different occlusal extensions of the pulp horns in the tooth to the right. (Not to scale)

Fig 4 Four root canals (arrows) in a cross section of an equine third premolar (upper jaw; 207); magnification: $2.7 \times$

1 mesio-buccal root, 2 disto-buccal root, 3 lingual root

a dentin, $\mathrm{B}$ alveolar bone

Fig 5 Two root canals (arrows) in a cross section of an equine third premolar (lower jaw; 307); magnification: 2.7 x

1 mesial root, 2 distal root

asterisk: side branch of the distal root canal

a dentin, $b$ enamel, $c$ cementum

Fig 6 Three root canals (arrows) in a cross section of an equine third premolar (lower jaw; 307); magnification: $2.7 \times$

1 mesial root, 2 distal root

a dentin, b enamel, c cementum

Fig 7 Three root canals (arrows) in a cross section of an equine third premolar (lower jaw; 307); magnification: $2.7 x$

1 mesial root, 2 distal root

a dentin, b enamel, c cementum

Fig 8 Root canal (arrow) in a cross section of an equine third premolar root (20 years old, lower jaw; 307); magnification: 25.5 x (inset: $8.25 \mathrm{x}$ ); note the slightly oblique course of the root canal a dentin, $B$ alveolar bone

Fig 9 Blood vessels (arrows) in the dental pulp of an equine third premolar root (19 years old, lower jaw; 307); paraffin section, Masson-Goldner stain, magnification: 255 x

Fig 10 "Canal" in the dental cementum bearing soft connective tissue (arrows); cross section of a lingual root of an equine third premolar (17 years old, upper jaw; 207); paraffin section, MassonGoldner stain, magnification: 255 x

c cementum, $d$ periodontal ligam
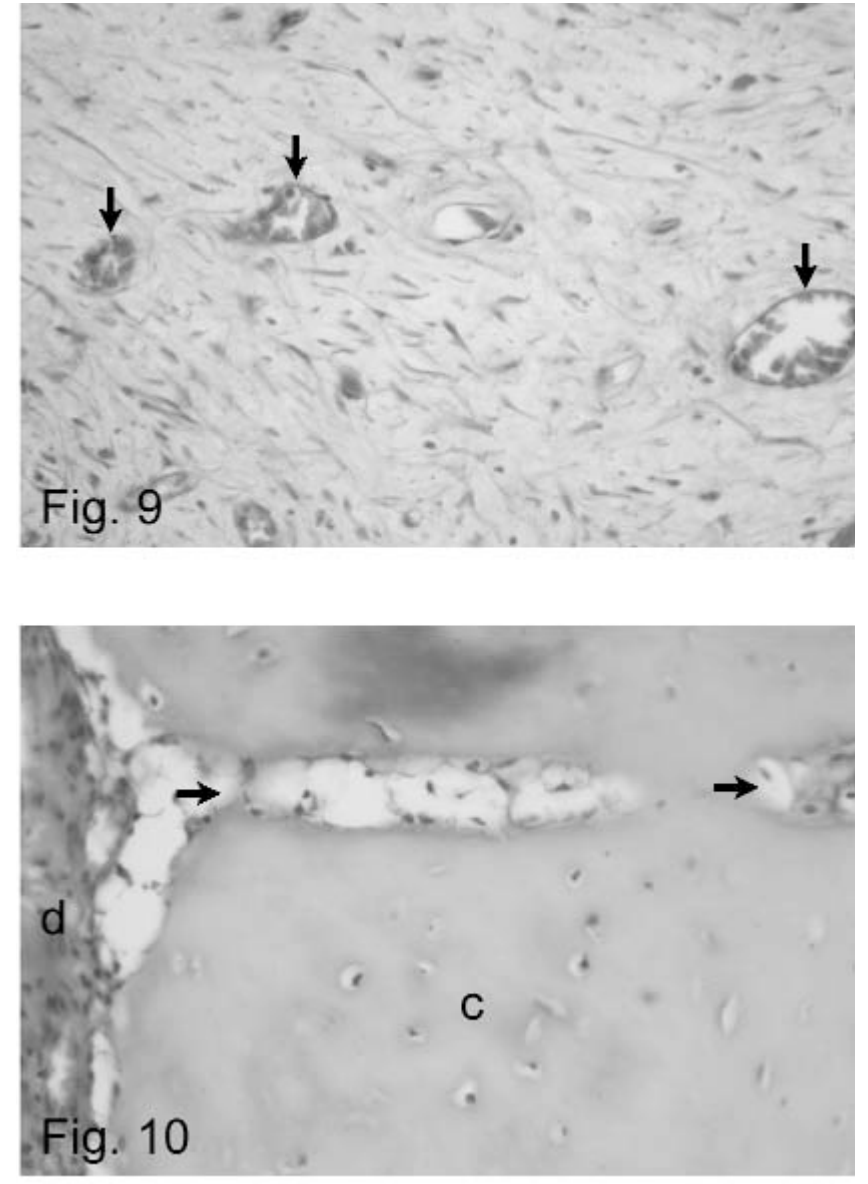
Histological controls: P3 and M1 (107/109/407/409) were isolated from the right upper and right lower jaw. Bony tissue was removed as described above. Then, the roots were inspected under the dissection microscope in order to check for a closure of the apical foramen. 28 teeth which - in this procedure - had been classified as "apical foramen: no" were then submitted to a histological decalcification process in EDTA with a subsequent histological standard procedure in order to make $6 \mu \mathrm{m}$ sections (see Westenberger 2002). The specimens were cut transversally $(n=10)$ or along their longitudinal axis $(n=18)$. These sections served to identify soft tissue inside the endodontic system as being a "vital" pulp. The presence of blood vessels containing blood cells was taken as a criterion for the vitality. The oldest specimen that could be obtained for such a histologic control was 21 years old.

The horses had been euthanised for medical reasons, but had no history of a dental disease. Information about the age of the horses were taken from the owners' documents. The youngest horse was 7 years, the oldest 27 years old. All of them were assigned to one of three age groups: horses younger than 15 years, 15-23 years old, or older than 23 years. Based on data from the literature, the age between 15 and 23 years seemed to be most critical in terms of discrepancies of data in the literature (Westenberger 2002).

\section{Results}

The pulp horns

The pulp horns of the cheek teeth were easy to identify in the cross sectioned third premolar, P3, and first molar, M1 (Fig. 1 and 2). Their size and number (Tab. 1) decreased with age.

Tab 1 Number of pulp horns, number of root canals, and presence of apical foramina in selected cheek teeth $(207,209,307,309)$ of horses of different age.

\begin{tabular}{|c|c|c|c|c|}
\hline \multirow{3}{*}{\begin{tabular}{|l}
$\begin{array}{l}\text { horses younger than } 15 \\
\text { years } \\
n=5\end{array}$ \\
number of pulp horns \\
\end{tabular}} & \multicolumn{2}{|c|}{ upper jaw } & \multicolumn{2}{|c|}{ lower jaw } \\
\hline & $\begin{array}{l}\text { P3 } \\
207\end{array}$ & $\begin{array}{l}M 1 \\
209\end{array}$ & $\begin{array}{l}\text { P3 } \\
307\end{array}$ & $\begin{array}{l}M 1 \\
309\end{array}$ \\
\hline & 5 & $5(6)^{*}$ & 5 & 5 or 4 \\
\hline number of root canals & 4 & 4 & 3 or 2 & 3 \\
\hline apical foramen & yes & yes & yes & yes \\
\hline \multirow{2}{*}{$\begin{array}{l}\text { horses } 15-23 \text { years old } \\
n=19\end{array}$} & \multicolumn{2}{|c|}{ upper jaw } & \multicolumn{2}{|c|}{ lower jaw } \\
\hline & $\begin{array}{c}\text { P3 } \\
207\end{array}$ & $\begin{array}{l}\text { M1 } \\
209\end{array}$ & $\begin{array}{c}\text { P3 } \\
307\end{array}$ & $\begin{array}{l}\text { M1 } \\
309\end{array}$ \\
\hline number of pulp horns & $5(0-6)^{*}$ & $0(5-6)^{*}$ & 5 or 0 & $0(3,4,5)^{*}$ \\
\hline number root canals & 4 & $4(3)^{*}$ & 3 or $2(4)^{*}$ & $3(4)^{*}$ \\
\hline apical foramen & $\begin{array}{l}\text { yes } n=13^{* *} \\
\text { no } n=6^{* *}\end{array}$ & $\begin{array}{l}\text { yes } n=12^{* *} \\
\text { no } n=7^{* *}\end{array}$ & $\begin{array}{l}\text { yes } \mathrm{n}=12^{* *} \\
\text { no } \mathrm{n}=7^{* *}\end{array}$ & $\begin{array}{ll}\text { yes } & n=12^{* *} \\
\text { no } & n=7^{* *}\end{array}$ \\
\hline \multirow{2}{*}{\begin{tabular}{|llll} 
horses older than 23 \\
years & & & \\
$n=7$ & & & \\
\end{tabular}} & \multicolumn{2}{|c|}{ upper jaw } & \multicolumn{2}{|c|}{ lower jaw } \\
\hline & $\begin{array}{l}\text { P3 } \\
207\end{array}$ & $\begin{array}{l}M 1 \\
209\end{array}$ & $\begin{array}{c}\text { P3 } \\
307\end{array}$ & $\begin{array}{l}\mathrm{MI} \\
309\end{array}$ \\
\hline number of pulp horns & $0(5 \text { or } 3)^{*}$ & $0(5)^{*}$ & 0 & 0 \\
\hline number of root canals & 4 & 4 & 3 or $2(4)^{*}$ & $3(2 \text { or } 4)^{*}$ \\
\hline apical foramen & no & no & no & no \\
\hline $\begin{array}{l}\text { * numbers given in bracke } \\
\text { only in single, individua } \\
* * n=\text { number of horses }\end{array}$ & $\begin{array}{l}\text { Its are except } \\
\text { I cases }\end{array}$ & numbers & ms of being & \\
\hline
\end{tabular}

In general, pulp horns had disappeared in P3 and M1 of the lower jaw in horses older than 23 years, however, they were still found in cheek teeth of the upper jaw in relatively old horses (25 years). In the first molar, pulp horns disappeared earlier than in the third premolar. The extension of the pulp horns towards the occlusal surface was markedly unsymmetrical in teeth with an extreme inclination of the occlusal surface (indicated schematically in Fig. 3).

\section{The root canals and the apical foramen}

The cross sections revealed that more than one root canal can occur in one root. In the upper jaw's cheek teeth, which usually had three roots, both of the buccal roots contained one root canal each, while in the lingual root there were two (Fig. 4). In the lower jaw's cheek teeth, which usually had two roots, there were many variations as to their root canals (Tab. 1). They shall be designated as four "versions". Version 1: Both roots contain one root canal each (Fig. 5); version 2: the mesial (rostral) root contains two root canals and the distal (caudal) contains one (Fig. 6); version 3: the mesial (rostral) root contains one root canal and the distal (caudal) contains two (Fig. 7); version 4: both roots contain two root canals each.

The width of the root canals decreased with age, but they never disappeared. They were still present in all samples of horses older than 23 years (Tab. 1), and the same was true even in a horse that was 27 years old.

All tooth samples from horses younger than 15 years had an apical foramen. In the group of horses that were 15-23 years old, an apical foramen was not always visible macroscopically, but it could be detected in cross sections under the dissection microscope in approx. two thirds of the specimens (Tab. 1). Figure 8 shows a sample from a 20 year old horse. In the third age group, i.e. horses older than 23 years, an apical foramen could not be seen even in the dissection microscope.

\section{The histological controls}

In the histological controls of teeth that had been classified as "apical foramen: no" (see above), no remnants of an apical foramen could be found - neither in cross sections nor in longitudinal sections.

All investigated teeth, even those whose cross sections had shown no apical foramen, still had root canals. They contained a loose connective tissue which was the dental pulp. Numerous profiles of blood vessels (some arterioles and many capillaries) containing erythrocytes were dispersed in it (Fig. 9). Signs of hemolysis were rare.

In the very old horses, the tip of the root consisted of cementum only. Along the root, the cementum - sometimes - contained profiles of small areas of loose connective tissue. These profiles appeared like "canals" entering the cementum from the side and took an irregular course within the cementum (Fig. 10). However, none of these formations were seen to be in continuation with the remnants of the vascularized pulp of the root canals.

\section{Discussion}

The endodontic system consists of the pulp horns, the common pulp chamber, and the root canals (Kirkland et al. 
1996). Descriptions of these compartments of the pulp cavity appear in great numbers in the literature, but the data are very heterogenous. In terms of closure of root canals, for instance, macroscopical and/or radiographical studies reported about an age of "20 years" (Finger 1920; Habermann 1963), or "18-20 years" (Joest et al. 1922), or "5-8 years after eruption" (Kirkland et al. 1996; Dixon 1999). In fact, there is a great heterogeneity especially in our group of horses that were 15-23 years old. But in this age group there are too many variations as to allow the establishment of an agerelated rule.

\section{The pulp horns}

In terms of closure of the pulp horns, our findings indicate that the teeth of the upper jaw are a bit "retarded" if compared with those of the lower jaw. The same is true for the P3 in comparison with the M1. Special attention should be paid to the group of the oldest horses (>23 years). Even though pulp horns are usually gone at this age, they may be found in P3 and $M 1$ of the upper jaw in some individuals anyway - with the chance of being openend when trimming the teeth. It should further be considered that pulp horns within one tooth may extend to different levels if there is an extreme inclination of the occlusal surface. This too should be taken in account when shortening the crown.

\section{The root canals}

The root canals persisted in all specimens of our study, i.e. up to the age of 27 years. The pulp was vascularized, no matter if an apical foramen was present or not. Blood vessels entering the pulp via other sites than an apical foramen - from the side instead of the tip of the radix, like in incisor teeth (Muylle et al. 1999) or via individual vascular canals that penetrate the cementum and dentin - have not been found yet. This requires a further investigation.

However, as the pulp is vascularized, two major issues can be considered. Firstly, the tooth is not "dead" in case of closure of the apical foramina - which is in contrast to the previous assumption of Zietzschmann and Krölling (1955). Secondly, the root canals may be affected by pathological disturbances of the endodontic system, mainly those of infectious kind. In such cases, related techniques of apicoectomy (Zetner and Eisenmenger 1980; Eisenmenger and Zetner 1982; Zetner 1989) are not simply dependent on the presence of root canals. Root-resection procedures are rather dependent on the number of root canals, and on their size.

As for the number of root canals, investigators often seemed to suppose that there is only one root canal in every root (for details see Westenberger 2002). However, in the upper jaw's cheek teeth both of their buccal roots contain one root canal each, while there are two in the lingual root. In the lower jaw's cheek teeth, there is a wide range of variations which have been indicated, so far, only in part by Kirkland et al. (1996). Due to these variations in number (and in size) of the root canals, the definite status of the individual cheek tooth is hardly predictable - especially as far as mandibular cheek teeth are concerned. This should be taken into account when choosing one of the two possibilities of surgical treatment, i.e. apicoectomy with extirpation of pulp, or conventional removal of the tooth.

\section{Literature}

Dixon P. M. (1999): Dental anatomy. in: Baker, G.J., and J. Easley (eds.): Equine dentistry. W.B. Saunders Company, Philadelphia, London, p. 3-28

Dixon P. M., W. H. Tremaine, K. Pickles, L. Kuhns, C. Hawe, J. McCann, B. C. McGorum, D. I. Railton and S. Brammer (2000): Equine dental disease. Part 3: a long-term study of 400 cases: disorders of wear, traumatic damage and idiopathic fractures, tumours and miscellaneous disorders of the cheek teeth. Equine vet. J. 32, 9-18

Eisenmenger E. und K. Zetner (1982): Tierärztliche Zahnheilkunde. Verlag Paul Parey, Berlin, Hamburg

Finger H. (1920): Beitrag zur Kenntnis der postembryonalen Entwikklung der Backenzähne des Pferdes. Dissertation Tierärztliche Hochschule Dresden

Habermann U. (1963): Zur röntgenologischen Darstellung der maxillären Backzähne des Pferdes. Dissertation Tierärztliche Hochschule Hannover

Joest E., A. Chorin, H. Finger und O. Westman (1922): Studien über das Backzahngebiss des Pferdes mit besonderer Berücksichtigung seiner postembryonalen Entwicklung und seines Einflusses auf den Gesichtsschädel und die Kieferhöhle. Verlag Richard Schoetz, Berlin

Kirkland K. D., G. J. Baker, S. Manfra Marretta, J. A. C. Eurell and J. M. Losonsky (1996): Effects of aging on the endodontic system, reserve crown and roots of equine mandibular cheek teeth. Am. J. Vet. Res. 57, 31-38

Muylle S., P. Simoens and H. Lauwers (1999): Age related morphometry of equine incisors. in: Muylle S.: Age-related morphology of equine incisors. University of Gent, Faculty of Veterinary Medicine, PhD Thesis, p. 123-144

Obiger G. (1939): Untersuchungen an den Pulpaösten der mandibulären Backzähne des Pferdes unter besonderer Berücksichtigung der Ersatzdentinbildung. Dissertation Universität Leipzig

Westenberger E. (2002): Cavum dentis und Pulpa dentis mandibulärer und maxillärer Backenzähne bei Pferden verschiedenen Alters. Dissertation Tierärztliche Hochschule Hannover

Zetner K. (1989): Equine apicoectomy. in: Veterinary dentistry '89. Proceedings of the Congress of the American Veterinary Dental College and Academy of Veterinary Dentistry, New Orleans, December 7-10, 1989, p. 104-105

Zetner K. und E. Eisenmenger (1980): Wurzelspitzenresektion zur Behandlung der Zahnfistel des Pferdes. in: Proceedings of the 13th Congress of the European Society of Veterinary Surgery, Budapest, June 5-7, 1980, p. 279-281

Zietzschmann O. und O. Krölling (1955): Lehrbuch der Entwikklungsgeschichte der Haustiere. 2. Aufl. Verlag Paul Parey, Berlin, Hamburg

Prof. Dr. H. Gasse

Anatomisches Institut

Tierärztliche Hochschule Hannover

Bischofsholer Damm 15

30173 Hannover

Germany

hagen.gasse@tiho-hannover.de 